\title{
Human Immunodeficiency Virus Can Affect the Semiology of Osteoarticular Infections?
}

\author{
Owonayo Oniankitan, Komi C. Tagbor, Kodjo Kakpovi, Eyram Fianyo, Prénam Houzou, \\ Viwalé E. S. Koffi-Tessio, Moustafa Mijiyawa
}

Rheumatology Department, CHU Sylvanus Olympio, Lomé, Togo

Email: Owonayo@yahoo.com

Received 14 September 2014; revised 14 October 2014; accepted 6 November 2014

Copyright (C) 2014 by authors and Scientific Research Publishing Inc.

This work is licensed under the Creative Commons Attribution International License (CC BY). http://creativecommons.org/licenses/by/4.0/

(c) (i) Open Access

\begin{abstract}
Objective: To compare the epidemiological, the clinical and the paraclinical profile of osteoarticular infections in HIV-positive patients and in HIV-negative patients. Patients and Methods: patients with Osteoarticular infections recognized on the basis of radioclinical and epidemiological arguments were included in this study. The comparison that was based on the existence or was not of HIV infection focused on various clinical and biological components. Of these 15,800 rheumatic patients admitted in 18 years, 461 have suffered from Osteoarticular infection (2.9\%). The 461 patient objects of this study were divided into 235 cases of infectious arthritis including 38 cases of co-infection with HIV and 225 cases of infectious spondylodiscitis including 21 cases of HIV coinfection. Results: There were 246 women (53.4\%) and 215 men (46.4\%) with a sex ratio of 1.1 . The mean age was $37.7 \pm 13.6$ years. The data comparison of HIV-negative patients and HIV-positive patients had not shown statistically significant difference in the infectious spondylodiscitis group and in the group of infectious arthritis patients. Only fever was statistically significant in both groups and weight loss in the group of infectious arthritis $(p<0.001)$. Conclusion: HIV seems not to particularly influence the semiological profile of Osteoarticular infections in Lomé.
\end{abstract}

\section{Keywords}

Black Africa, Spondylodiscitis, Arthritis, HIV

\section{Introduction}

Human Immunodeficiency Virus/Acquired Immune Deficiency Syndrome (HIV/AIDS) is a challenge for the world and a major problem of public health in sub-Saharan Africa. Many rheumatologic manifestations were described during HIV infection and several prospective cross-sectional studies allow assessing the prevalence of

How to cite this paper: Oniankitan, O., Tagbor, K.C., Kakpovi, K., Fianyo, E., Houzou, P., Koffi-Tessio, V.E.S. and Mijiyawa, M. (2014) Human Immunodeficiency Virus Can Affect the Semiology of Osteoarticular Infections? Open Journal of Rheumatology and Autoimmune Diseases, 4, 235-239. http://dx.doi.org/10.4236/ojra.2014.44032 
the rheumatic manifestations in this field [1]-[7]. Aseptic arthritis is much more frequent than the septic arthritis in HIV infected patients [8]-[10]. Osteoarticular infection rates in HIV-infected patients have been widely variable in previous reports. In a series evaluating 101 HIV-infected patients, none developed an osteoarticular infection [11]. Other studies report osteoarticular infections as rare manifestations in HIV-infected patients, with 14 cases (0.3\%) found among 4023 patients [7] and 23 cases found among 1515 patients [12]. Other studies have shown a higher prevalence of osteoarticular infections [9]. It is stated in these reports that personal characteristics other than HIV infection may have played a role in the pathogenesis of these infections, although less frequent osteoarticular infections remain one of the daunting complications of infection to human immunodeficiency virus. HIV/AIDS is responsible for various complications during its evolution and can change the course and clinical manifestations of some diseases [4] [7]. However, in our environment where the technical level is insufficient or missing, the diagnosis of osteoarticular infection is often a presumptive diagnosis based on clinical data, standard X-ray and treatment. The aim of this study was to compare respectively semiological aspects of the spondylodiscitis and the infectious arthritis in HIV-infected patients to those patients who are not HIV infected.

\section{Patients and Methods}

This study was retrospectively performed on a series of cases admitted in the Department of Rheumatology, University Hospital Sylvanus Olympio, Lomé, Togo’s capital between January 1989 and December 2007. The series included all patients diagnosed with infectious spondylodiscitis or septic arthritis in which retroviral serology was carried out systematically. The study was approved by the ethics committee. The diagnosis of infectious spondylodiscitis was based on the radioclinical and epidemiological arguments, and that of septic arthritis was based on the radioclinical and biological arguments. The comparison that was based on the existence or not of HIV infection focused on various clinical and biological components. Socio-demographic and epidemiological characteristics; co-morbidity; clinical, radiological and biological data were collected. Each patient has been submitted to radiography, a complete blood count, measurement of the erythrocyte sedimentation rate, a retroviral serology. No patient has been subjected to bone scan or magnetic resonance imaging (MRI) due to the absence of scintigraphy and MRI in Togo at the time of the study. In case of underlining of a given infectious entrance, a swab has been done in view of a cytological and bacteriological test. The combination of fatigue, anorexia, weight loss and pallor or the presence of at least three of these symptoms was considered as an alteration of the general condition. A weight loss greater than $10 \%$ was considered massive and a weight loss below $10 \%$ was considered moderate. Fever was defined as a temperature above $37.5^{\circ} \mathrm{C}$ and leukocytosis defined as a leukocytic count $>11,000 / \mathrm{mm}^{3}$. Erythrocyte sedimentation rate (ESR) greater than $20 \mathrm{~mm}$ in the first hour was considered to be high. The data collected were analyzed by the software SPSS version 17.0. Comparisons of variable were performed with Pearson Chi2 test. The comparison was statistically significant for a $\mathrm{p}<0.05$.

\section{Results}

Fifteen thousand eight hundred patients (6737 men and 9068 women) were admitted in the Department of Rheumatology during the study period. Of the 15,800 patients, 461 suffer from infectious osteoarthritis (2.9\%). The infectious spondylodiscitis was observed in 226 (97 men and 129 women) of 461 patients (49\%) and infectious arthritis among the 235 (118 men and 117 women) others (51\%). The mean age of patients with infectious spondylodiscitis was 39.4 years and the mean duration of the disease was $10.3 \pm 14.5$ months. The mean age of the patients with infectious arthritis was 36.1 years and the mean duration of the disease of $5.7 \pm 13.6$ months. Table 1 provides the semiological comparison of the 205 infectious spondylodiscitis affected patients without HIV co-infection and 21 cases of infectious spondylodiscitis affected patients with HIV co-infection. Comparison of the mean age of the patients in the two groups (37 years in HIV-negative patients and 34 years in HIVpositive patients) had not shown statistically significant difference. It was the same for the semiological data studied except the fever. Table 2 provides the semiological comparison of the 197 septic arthritis affected patients without HIV co-infection and 38 cases of septic arthritis affected patients with HIV co-infection. The comparison of the mean age of the patients in two groups (39 years in HIV-negative patients and 41 years in HIV-positive) had not shown statistically significant difference. It was the same for the semiological data studied except the fever and the weight loss. 
Table 1. Comparison of data from the 205 HIV-negative patients and the 21 HIV-positive patients in the infectious spondylodiscitis patients group.

\begin{tabular}{cccc}
\hline & HIV-Negative & HIV-Positive \\
Number (\%) & $P^{*}$ \\
Female & $116(57)$ & $13(62)$ & NS $^{*}$ \\
Progressive Start Mode & $78(38)$ & $6(28)$ & NS \\
Inflammatory Pain & $131(64)$ & $17(81)$ & NS \\
Massive Weight Loss & $195(95)$ & $20(95)$ & NS \\
Existence of Fever & $97(47)$ & $17(81)$ & Significant \\
Dorsal Localization & $54(12)$ & $4(19)$ & NS \\
Lumbar Location & $173(83)$ & $14(67)$ & NS \\
Gibbosity & $99(48)$ & $11(52)$ & NS \\
Neurological Complication & $125(61)$ & $17(81)$ & NS \\
Accelerated VS & $188(92)$ & $19(90)$ & NS \\
Leukocytosis & $54(26)$ & $8(38)$ & NS \\
Koch's Bacillus & $197(96)$ & $18(86)$ & NS \\
\hline
\end{tabular}

$\mathrm{P}^{*}$ Statistically significant if $\mathrm{p}<0.05$; NS ${ }^{*}$ Not statistically significant.

Table 2. Comparison of data from the 197 HIV-negative patients and the 38 HIV-positive patients in the septic arthritis patients group.

\begin{tabular}{|c|c|c|c|}
\hline & $\begin{array}{c}\text { HIV-Negative } \\
\text { Number (\%) }\end{array}$ & $\begin{array}{l}\text { HIV-Positive } \\
\text { Number (\%) }\end{array}$ & $\mathrm{P}^{*}$ \\
\hline Female & $96(49)$ & $21(55)$ & $\mathrm{NS}^{*}$ \\
\hline Brutal Start Mode & $113(57)$ & $27(72)$ & NS \\
\hline Existence of Fever & $126(64)$ & $25(67)$ & NS \\
\hline Massive Weight Loss & $106(54)$ & $32(84)$ & Significant \\
\hline Existence of Infectious Gateway & $68(35)$ & $14(37)$ & NS \\
\hline Mono-Arthritis & $167(85)$ & $29(76)$ & NS \\
\hline Major Functional Impotence & $145(74)$ & $33(87)$ & NS \\
\hline Existence of Franc Infectious Syndrome & $158(80)$ & $36(38)$ & Significant \\
\hline Lymphadenopathy Satellite & $29(15)$ & $11(29)$ & Significant \\
\hline Accelerated VS & $174(88)$ & $36(95)$ & NS \\
\hline Leukocytosis & $78(40)$ & $10(26)$ & NS \\
\hline
\end{tabular}

$\mathrm{P}^{*}$ Statistically significant if $\mathrm{p}<0.05$; NS ${ }^{*}$ Not statistically significant.

\section{Discussion}

HIV seen as a major risk of infectious spondylodiscitis represents it in only 9\% in our series. This small proportion was found in the series of Schulzer et al. [13]. Prospective studies with rigorous statistical analysis will allow establishing the existence of any causal link between the frequency of infectious spondylodiscitis in our countries and the increase of HIV infection. The mean age of the patients affected by the infectious spondylodiscitis in our series was 37 ans in HIV negative patients and 34 in HIV positive patients without statistically significant differences. The relative youth of the population suffering from infectious spondylodiscitis in our series was comparable to that of Meddeb et al. [14] and can be explained by the relatively young age of the African peoples and the importance of risk factors that are unfavourable living conditions of African populations. As in the present study, in the series of 188 patients with osteoarticular tuberculosis studied, the distribution was similar in patients who were HIV-positive and HIV-negative [15]. However, and unlike the present study, in patients with spinal disease, there was a predominance of lumbar lesions in patients who were HIV-positive [15]. In the present series, the presence of fever with a statistically significant difference in immunocom promised patients suffering from infectious spondylodiscitis is only a reflection of the clinical manifestations of acquired immunodeficiency syndrome [16]. There are many similarities between the clinical presentations of patients with tuberculosis and patients with advanced HIV disease. Both are of insidious onset and cause debility, wasting, fevers, and night sweats [17]. In our series the sedimentation rate was accelerated in the two groups. This 
result was found in the series of Meddeb et al. [14]. In our series hinge dorso-lumbar spine is the seat of choice for infectious spondylodiscitis in both groups. This result is consistent with those of Larget-Piet et al. [18] and Maftah et al. [19]. However, in the series of Sakho et al. [20] the dorsal spine is a favourite site of infectious sopondylodiscitis. The gibbosity was found in half of the patients in the two groups in the present study is comparable to that found in the series of Sakho et al. [20]. The importance of the gibbosity and neurological disorders observed also by Maftah et al. [19] and Oniankitan et al. [21] reflects the frequency of forms advanced disease in these series.

In the present study, the septic arthritis was found predominantly in young patients in the two groups. This result was found in the series of Bileckot et al. [22], Ntsiba et al. [23] and Oniankitan et al. [24]. The septic arthritis is conspicuous by the existence among the HIV/AIDS risk factors. As in the series of Bileckot et al. [25], AIDS does not confer any bacteriological and evolutionary feature in our series. Monoarticular infection is predominant in both groups in our study. However, in the series of Bileckot et al. [25], the infringement is polyarticular in patients with HIV.

\section{Conclusion}

HIV seems not to particularly influence the semiological profile of Osteoarticular infections in Lomé where the diagnosis of osteoarticular infection is often a presumptive diagnosis. But the diagnosis of HIV-positive patients with osteoarticular infections will be necessary for correct management.

\section{References}

[1] Yao, Q., Frank, M., Glynn, M. and Altman, R.D. (2008) Rheumatic Manifestations in HIV-1 Infected In-Patients and Literature Review. Clinical and Experimental Rheumatology, 26, 799-806.

[2] Rogeaux, O., Fassin, D. and Gentilini, M. (1993) Prevalence of Rheumatic Manifestations in Human Immunodeficiency Virus Infection. Annales de Médecine Interne, 144, 443-448.

[3] Saraux, A., Jousse, S., Roudant, A. and Devuchelle, V. (2006) Particularites des infections osteoarticulaires chez les sujets VIH positifs et les toxicomanes. Revue du Rhumatisme, 73, 163-167. http://dx.doi.org/10.1016/j.rhum.2005.10.014

[4] Njobvu, P., Mcgill, P., Kerr, H. and Poppee, J. (1998) Spondylarthropathy and Human Immunodeficiency Virus Infection in Zambia. The Journal of rheumatology, 25, 1553-1559.

[5] Kaddu-Mukasa, M., Ssekasanvu, E., Ddumba, E., Thomas, D. and Katabira, E.T. (2011) Rheumatic Manifestations among HIV Positive Adults Attending the Infectious Disease Clinic at Mulago Hospital. African Health Sciences, 11, 24-29.

[6] Reveille, J.D. and Williams, F.M. (2006) Infection and Musculoskeletal Conditions: Rheumatologic Complications of HIV Infection. Best Practice \& Research. Clinical Rheumatology, 20, 1159-1179. http://dx.doi.org/10.1016/j.berh.2006.08.015

[7] Ventura, G., Gasparini, G., Lucia, M.B., Tumbarello, M., Tacconelli, E., Caldarola, G., et al.. (1997) Osteoarticular Bacterial Infections Are Rare in HIV-Infected Patients.14 Cases founds among 4023 HIV-Infected Patients. Acta Orthopaedica Scandinavica, 68, 554-558. http://dx.doi.org/10.3109/17453679708999025

[8] Marquez, J., Restrepo, C.S., Candia, L., Berman, A. and Espinoza, L.R. (2004) Human Immunodeficiency Virus-Associated Rheumatic Disorders in the HAART Era. The Journal of rheumatology, 31, 741-746

[9] Louthrenoo, W. (2008) Rheumatic Manifestations of Human Immunodeficiency Virus Infection. Current Opinion in Rheumatology, 20, 92-99.

[10] Munoz-Fernandez, S., Cardenal, A., Balsa, A., Quiralte, J., del Arco, A., Pena, J.M., et al. (1991) Rheumatic Manifestations in 556 Patients with Human Immunodeficiency Virus Infection. Seminars in Arthritis and Rheumatism, 21, 3039. http://dx.doi.org/10.1016/0049-0172(91)90054-4

[11] Berman, A., Espinoza, L.R., Diaz, J.D., Aguilar, J.L., Rolando, T., Vasey, F.B., et al. (1988) Rheumatic Manifestations of Human Immunodeficiency Virus Infection. The American Journal of Medicine, 85, 59-64. http://dx.doi.org/10.1016/0002-9343(88)90503-7

[12] Busch, V.J., Regez, R.M., Heere, B. and Willems, W.J. (2007) Osteoarticular Infections in HIV-Infected Patients: 23 Cases among 1515 HIV-Infected Patients. Acta Orthopaedica, 78, 786-790. http://dx.doi.org/10.1080/17453670710014554

[13] Schulzer, M., Fitzgerald, J.M., Enarson, D.A. and Grzybowski, S. (1992) An Estimate of the Future Size of the Tuberculosis Problem in Sub-Sahara Africa, Resulting from HIV Infection. Tubercle and Lung Disease, 73, 52-58. 
http://dx.doi.org/10.1016/0962-8479(92)90080-4

[14] Meddeb, N., Rammeh, N., Chahed, M., Sahli, H., Elleuch, M., Cheour, E., Zouari, B. and Sellmi, S. (2002) Aspects actuels du mal de Pott en Tunisie. A propos d’une série de 29 cas. Bulletin de la Société de pathologie exotique, 95, 269-271.

[15] Jellis, J.E. (1996) Orthopaedic Surgery and HIV Disease in Africa. International Orthopaedics, 20, 253-256. http://dx.doi.org/10.1007/s002640050074

[16] CDC (1994) Revised Classification System for Human Immunodeficiency Virus Infection in Children Less than 13 Years of Age. Morbidity and Mortality Weekly Report, 43, 1-10.

[17] Jellis, J.E. (2002) Human Immunodeficiency Virus and Osteoarticular Tuberculosis. Clinical Orthopaedics and Related Research, 398, 27-31. http://dx.doi.org/10.1097/00003086-200205000-00005

[18] Larget-Piet, B. and Martigny, J. (1995) Bacterial Spondylodiscitis. Etiology, Diagnosis, Development, Prognosis, Treatment. Revue du praticien, Paris, 45, 915-920.

[19] Maftah, M., Lmejjati, M., Mansouri, A., El Abbadi, N. and Bellakhdar, F. (2001) Mal de Pott. A propos de 320 cas. Médecine du Maghreb, 90, 19-22.

[20] Sakho, Y., Badiane, S.B., N’Dao, A.K., N’Diaye, A., Gueye, M. and N’Diaye, I.P. (2003) Pott's Disease in Senegal. European Journal of Orthopaedic Surgery \& Traumatology, 13, 13-20. http://dx.doi.org/10.1007/s00590-002-0057-y

[21] Oniankitan, O., Bagayogo, Y., Fianyo, E., Koffi-Tessio, V., Kakpovi, K., Tagbor, K.C., et al. (2009) Spondylodiscitis at a Hospital Outpatient Clinic in Lome, Togo. Médecine Tropicale: Revue du Corps de Santé Colonial, 69, 581-582.

[22] Bileckot, R. and Miakoundoba, R.C. (2007) Aspects bactériologiques et évolutifs des arthrites septiques à Brazaville. Bulletin de la Société de pathologie exotique, 100, 308.

[23] Ntsiba, H., Bazébissa, R., Lamini, N. and Yala, F. (2004) Cent cas d'arthrites septiques du genou en zone intertropicale. Bulletin de la Société de pathologie exotique, 97, 244-246.

[24] Oniankitan, O., Bagayogo, Y., Fianyo, E., Koffi-Tessio, V., Kakpovi, K., Tagbor, K.C., Houzou, P. and Mijiyawa, M. (2011) Infectious Arthritis in Hospital Patients in Lomé, Togo. Médecine Tropicale: Revue du Corps de Santé Colonial, 71, 61-62.

[25] Bileckot, R., Ntsiba, H., Okong, D. and Ognami, J.B. (1994) Arthritis in Black Africa: A Review of 473 Cases Seen in Congo. Revue du Rhumatisme, 61, 260-265. 
Scientific Research Publishing (SCIRP) is one of the largest Open Access journal publishers. It is currently publishing more than 200 open access, online, peer-reviewed journals covering a wide range of academic disciplines. SCIRP serves the worldwide academic communities and contributes to the progress and application of science with its publication.

Other selected journals from SCIRP are listed as below. Submit your manuscript to us via either submit@scirp.org or Online Submission Portal.
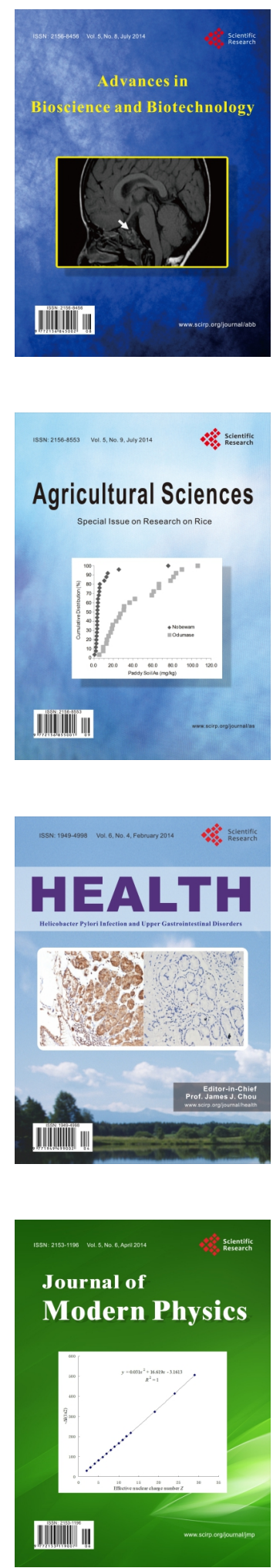
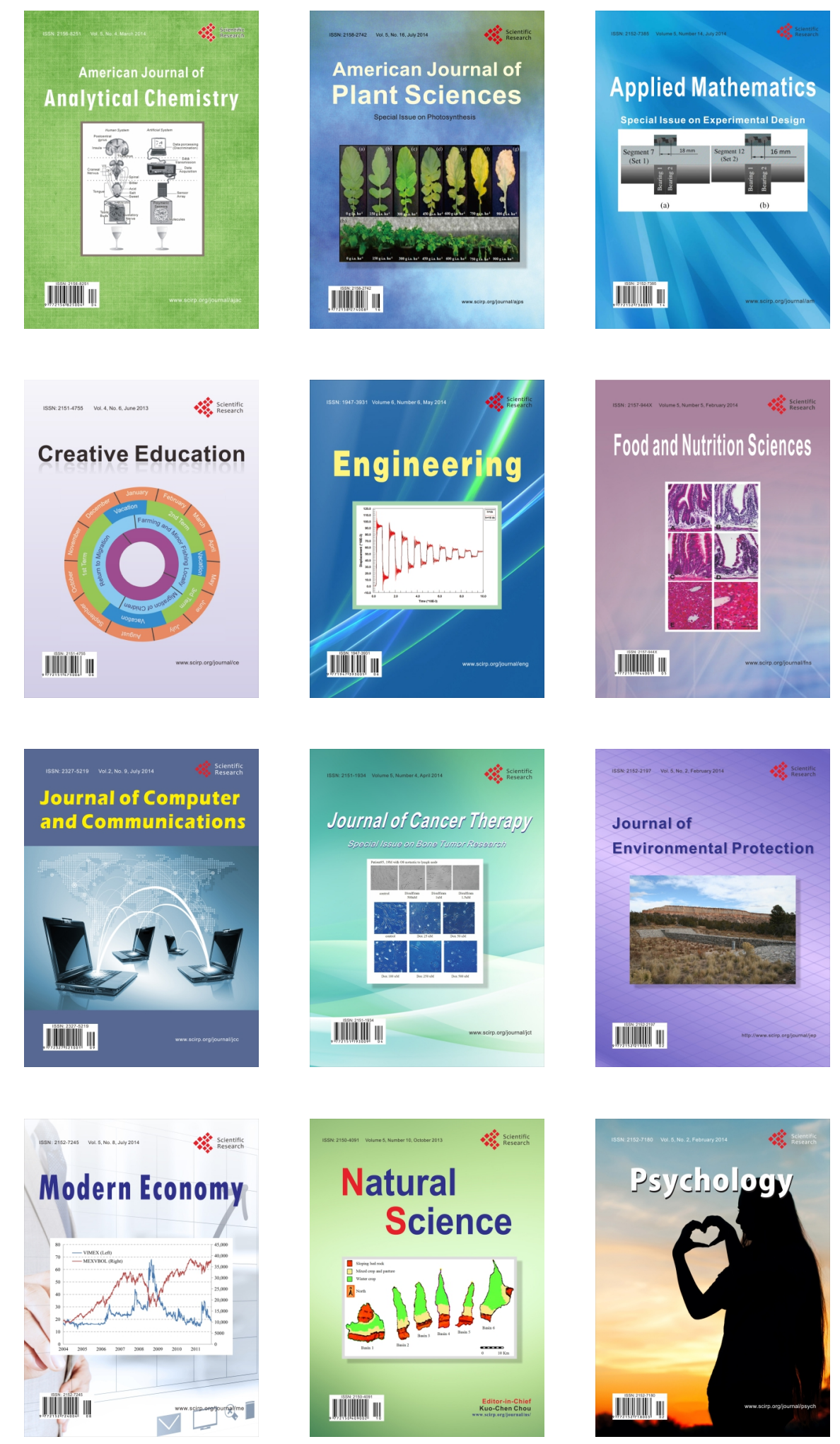